\title{
2. Governance of Environmental Risk: new approaches to managing stakeholder involvement
}

\author{
Suzanne Benn ${ }^{\mathrm{a}}$, Dexter Dunphy ${ }^{\mathrm{b}}$ and Andrew Martin ${ }^{\mathrm{c}}$
}

\begin{abstract}
Disputes concerning industrial legacies such as the disposal of toxic wastes illustrate changing pressures on corporations and governments. Business and governments are now confronted with managing the expectations of a society increasingly aware of the social and environmental impacts and risks associated with economic development and demanding more equitable distribution and democratic management of such risks. The closed managerialist decision-making of the powerful bureaucracies and corporations of the industrial era is informed by traditional management theory which cannot provide a framework for the adequate governance of these risks. Recent socio-political theories have conceptualised some key themes that must be addressed in a more fitting approach to governance. We identify more recent management and governance theory which addresses these themes and develop a process-based approach to governance of environmental disputes that allows for the evolving nature of stakeholder relations in a highly complex multiple stakeholder arena.
\end{abstract}

Keywords: Governance, stakeholder relations, management theory, environmental risk

\footnotetext{
a School of Management, University of Technology Sydney, PO Box 123, Broadway NSW 2007 Australia; Suzanne.Benn@uts.edu.au

b School of Management, University of Technology Sydney, PO Box 123, Broadway NSW 2007

Australia; Dexter.Dunphy@uts.edu.au

c Faculty of Law, University of Sydney, 2006, Australia; amartin1@bigpond.net.au
} 


\subsection{Introduction}

A series of corporate scandals and disputes over industrial legacies such as toxic wastes has put public pressure on corporations to conduct their business within a moral context, which entails anticipating and appreciating their effects on communities (Dawson, 2004). Key examples such as notorious episode of Love Canal have focussed public attention on incidents such as toxic materials and wastes. Corporations are increasingly required to move from a system of governance based on agency theory and an inwardly focused set of rules, procedures and codes of practice to a form of governance that allows for the evolving nature of stakeholder relations in a highly complex multiple stakeholder arena (Clarke, 2004). As corporate credibility is called into question, other traditional institutional sources of authority and legitimacy are also challenged by a highly reflexive public (Beck, 1992; Beck, 1999). Hence both business and governments need to reframe their internally-focussed perspective on governance to one that allows for communicating and decision-making on social and environmental issues with very different sets of stakeholder expectations (Dawkins, 2004). Disputes concerning industrial legacies such as the disposal of toxic wastes illustrate these changing pressures on corporations and governments. Both must now address the expectations of a society increasingly aware of the social and environmental risks associated with economic development and demanding that these risks be distributed more equitably and managed more democratically (Livesey, 2003).

The papers in this collection explore a range of factors that must be taken into consideration in governance for such decision-making, taking the case example of the disposal of HCB waste stored by Orica at their plant in Botany, Sydney. This paper 
aims to set the backdrop to the considerations raised by later papers that must be factored into new considerations of appropriate governance. These considerations include access to resources (Jensen-Lee, this volume); the relationship between different forms of knowledge (Healy, this volume) identity and symbolic capital (Benn and Jones, this volume); access to information and systems of supervision of risk that impact on its distribution (James, this volume).

In our overarching paper, we aim to provide a review of current understandings of what could be appropriate governance of multiple stakeholder decision-making on environmental and social issues and to develop a generic approach to managing stakeholder involvement. By appropriate governance we mean the policies, structures and processes that enable control and coordination of stakeholder decision-making and that will facilitate the development of a set of shared values concerning the issue in question (Stewart and Jones, 2003). Our definition of governance is broad and contemporary - relating not primarily to the activities of government but to the processes of interactions between social actors, groups and both public and private institutions (Kooiman, 1993). This understanding does not presume a decline of the state but rather a more interactive state where public-private interaction enables sustaining coordination and coherence between a wide variety of actors (Pierre, 2000). In addressing this aim, we firstly review the extent to which traditional organizational management and governance theory and practice deal with decision-making in situations where social and environmental issues and impacts that concern multiple stakeholders are involved. 


\subsection{Themes in traditional management theory}

\subsection{Resource-based and strategic management theory}

Two competing approaches to future planning and decision-making dominate contemporary organizational management literature. These are resource-based theory and strategic management theory. Both have only a limited capability to address issues of redistribution, inclusion and equity in the management of risk. Basically both resource-based and strategic management theories assume that organizations are 'narcissistic and self-serving' (Starkey and Crane, 2003: 229). Both theories privilege economic development and economic growth, the pursuit of individual interests and technocratic innovation (Crane, 2000).

Strategic management theory, still the dominant theory espoused in business schools and by academic management theorists, largely focuses on the company and its external competitive environment (eg Porter, 1980) ignoring the value of the natural environment. Resource-based theory is a more recent development and also exercises a strong influence on management practice, in particular challenging the external focus of traditional strategic management. It highlights the need for a fit between the external business environment and the more intangible and non-imitable features of the organization such as its skilled personnel ('human resources') (Drucker quoted in Kochan, 2003). Positive community relationships and NGO partnerships are another way of developing a strategically important resource based on human capital 
(Elkington, 1998). Through the lens of this theory, bridging relationships to external organizations and community bodies builds reputational and social capital - both tradeable resources (Adler and Kwon, 2002).

Both traditional strategic management and resource-based theory largely ignore the natural environment - the source of material resources for all forms of organizations. Their highly instrumental and competitive approaches have limited compatibility with a governance system emphasising meeting the expectations of a range of stakeholders and generating shared values and perspectives on shared problems.

\subsection{Stakeholder theory}

Even more recently, versions of resource-based theory that take into account relations with stakeholders external to the organization, have been merged with traditional corporate social responsibility (CSR) theories to be reconceptualised as 'stakeholder theory.’ According to UK Government official CSR website, 'CSR encourages companies to look at a wider range of stakeholder interests, which as well as bringing social and environmental benefits, can also be good for business'. For instance, 'It can widen a company's understanding of its potential risks and opportunities' (CSR Gov UK, 2006). Stakeholder theory conceptualizes the managing of stakeholder relations and theorises their importance to an organization and has been increasingly applied to both public and private sector organizations (see for example: Waddock, Bodwell, and Graves, 2002; Warhurst, 2001; Zadek, 2001). A stakeholder is 'any group or individual 
who can effect or is affected by the achievement of the organization's objectives' (Freeman, 1984: 46). In this theory, a successful organization is one which at least satisfies but preferably adds value for all stakeholders, not just shareholders. Some writers have made serious attempts to go further and conceptualise an 'ecocentric' organization which could feature the natural environment as a key stakeholder (Starik and Rands, 1995). According to Shrivastava (1995: 130):

Organizations in the ecocentric paradigm are appropriately scaled, provide meaningful work, have decentralised participative decision-making, have low earning differentials among employees, and have non-hierarchical structures. They establish harmonious relationships between their natural and social environments. They seek to systematically review natural resources and to minimise waste and pollution.

In general, ecocentric management theorists hold the view that significant value changes are required for a corporation to integrate sustainability into their business operations. For instance, Gladwin, Kennelly and Krause (1995: 899) argue that these values include: 'stewardship, equity, humility, permanence, precaution and sufficiency’. According to these broad versions of stakeholder theory, governance for social and environmental risk would be a matter of organizations internalising their social and environmental costs.

2.2.1 Limitations of stakeholder theory 
Nevertheless stakeholder theory has only a limited capacity to inform governance systems that would guarantee the equitable management of risk. For example, it does not show how to operationalise a system of governance that integrates the concerns of humans and non-humans as stakeholders. The 'ecocentric' theorists draw mainly on industrial ecology (Ehrenfeld, 2000) and natural capitalism models (Hawken, Lovins, Lovins, 1999) to explain how corporations can operationalise economic and environmental goals simultaneously. Both industrial ecology and natural capitalism rest upon technocentric principles. Neither is concerned with the principles of participatory or inclusive decision-making. New technologies will be a vital element in achieving sustainability but 'techno-fixes' will be insufficient solutions in themselves. No matter how sophisticated the technology, in the end people determine whether the technology works and to what ends.

Another limitation relates to the underlying constructs of narrow and broad stakeholder theories. Narrow stakeholder theory is based on concepts of agency theory and individualism while the broad version is based on stewardship theory and the obligations of the collective (Sundaramurthy and Lewis, 2003). However, governance, stakeholder and sustainability are loose terms, readily deployed into the rhetoric of a range of vested interests. Hence we have the broad version of stakeholder theory espoused in the rhetoric of 'green evangelism' and the 'win-win-win' case for sustainability (See for example: Grayson and Hodges, 2004; Warhurst, 2001). This interpretation tends to gloss over any conflict between economic development and sustainability values (Newton and Harte, 1997). Consequently the approach lacks a 
critical perspective on the power relations within and between stakeholder groups (Banerjee, 2005).

In the rhetoric of traditional management discourse, good governance is about achieving the best management of organizational assets and resources. According to Clarke (2004), this point of view is based on the assumption that if systems of control are not implemented, the behaviour of managers will be self-serving. So broad stakeholder theory is seen as limited by issues of multiple accountability and weakening agency (Bergkamp, 2002; Sternberg, 2000). If organizations are answerable to all stakeholders, so the narrow stakeholder theorists argue, then accountability is lost. As Bergkamp (2002: 147) puts the narrow stakeholder case:

Measuring performance against a profit maximisation objective is relatively easy but measuring performance against the objective of balanced stakeholder benefits is fraught with difficulty.

This instrumental perspective highlights a problem common to all streams of traditional management theory. It does not address the ethical guidelines which must underpin a more inclusive and ecologically equitable governance system for the management of risk (Grace and Cohen, 1998). As Orts points out, some moral issues, such as the obligation to consider the impact of environmental risks, are 'more important than stakeholder theory can accommodate’ (Orts, 2002: 228). Some scholars have argued that instead of the endless search for stakeholder priority we should be looking to set these issues in law in the form of a 'licence to operate' (Banerjee, 2005; Elkington, 1998). Others put the point that these measures will only be meaningful if they emerge 
from the ‘moral transformation’ of corporate leaders an issue on which stakeholder theory is silent (Crane, 2000: 673).

Even stakeholder theory, despite its promises, does not offer an alternative operational framework for implementing an integrated perspective on governance on social and environmental issues such as are associated with industrial toxic legacies or other examples of negative impact on society and the natural environment. It remains conceptually limited by the pluralist assumption that all stakeholders can compete with equal resources and information in the decision-making arena. Where there are multiple and diverse stakeholders and disparities of power, stakeholder theory offers no constructive guidelines for the creation of effective governance systems that will produce equitable outcomes. As we have argued, in practice disparities in power, diversities of interests and conflicting ethical principles in the management of risk are downplayed in an eager approach to get business on board the 'sustainability makes good business sense' bandwagon. Domination of the weak by the strong is often concealed in consensus based dialogue and ethical principles compromised in the rush to achieve a pragmatic solution. Stakeholders in environmental disputes, for instance, may steer discussions towards trade-offs or reframing of issues in order to achieve resolution. As Blattberg (2000) points out, management theory on stakeholder interaction basically espouses the instrumental notion that corporations should take a more responsible position in terms of dealing with these risks because it is better for their longterm profit-making. As in the case of the HCB dispute, the local community is not seen to be of any intrinsic value to the company. 
Leading management theories have major limitations in achieving inclusion and equity through stakeholder interactions. The theories are either constrained by narrow concepts of economic development and contestable approaches to shareholder accountability or lost in a directionless argument concerning stakeholder priorities. We conclude therefore that the leading forms of contemporary management theory provide little help in constructing an effective multiple stakeholder governance system for dealing with environmental or social negative impacts and risks. They only serve to reinforce the notion that the corporation, operating as a set of independent fragments (such as internal and external stakeholders, shareholders, the natural environment etc), hunts for profit as a value conceptually distinct from all others. We take Blattberg's view (2000: 180) that the model for responsible corporate governance would be one which would conceive of the corporation as a community embedded within a community, one where the various risks and goods at stake in stakeholder claims are seen as integrated with each other open to a 'non-compromising reconciliation as a means of overcoming conflicts between them'. Rather than negotiation, the model for governance would facilitate conversation and critical debate. Simply put, the model would allow for the corporation to act responsibly in all its activities (Blattberg 2000: 183).

\subsection{Themes in socio-political theory}

\subsection{Traditional versions of democratic theory}


In this section we look to developments in socio-political theory for guidance on a new approach to such needed systems of governance. As a number of scholars have argued, traditional systems of democracy are constrained at their ideological base in terms of preventing and managing these contemporary forms of risk (eg Eckersley, 1992; 2004). On the one hand, the principles of economic liberalism such as minimalist government, individualism and market fundamentalism are characteristically weak in providing the protection and management of public goods (Eckersley, 1992; Stewart and Jones, 2003). On the other, social democracy's dependence on state intervention and on bureaucratic administrative and planning systems often results in cumbersome decisionmaking procedures which can minimise public participation and review processes and engagement, thus limiting the collaboration needed for effective participatory risk management and the development of local innovative solutions to environmental problems (Farrell and Morris, 2003; Goodin, 1992).

An increasing number of political theorists now argue that neither system is suitable for dealing with multiple stakeholder decision-making involving complex issues of social and environmental impact and risk. Both points of view rest on shared understandings of liberal pluralism: both aim 'to reach a fair and efficient compromise' between differing individual points of view (Miller, 1993: 74). When powerful actors such as corporations have considerable economic resources and strategic interests at stake in the allocation and management of risk, the problems of achieving fair and reasonable assessment of individual preferences are often compounded. 
The key principle of the pluralist tradition is the competition between interest or pressure groups which are seen as composed of coalitions of like-minded citizens. The assumption is that all citizens have similar capacity (such as time and information) to form interest groups. Many minorities which do not have this capacity are effectively excluded or their role is minimised. Nor does pluralist theory give consideration to the potentially diverse make up of any particular interest group - homogeneity within the group is assumed regardless of diversity within a group.

These issues become further problematic when alternatives presented to voters involve highly technical and interdisciplinary areas of knowledge associated with high degrees of uncertainty. The dependence of many environmental decisions on knowledge of this kind further compromises the capacity of a pluralist system to ensure all interest groups are equally equipped with the solution-finding capacity needed to fully understand and defend their interest position or reach the equitable compromise (Eckersley, 2004).

These limitations underpinning the traditional systems of democracy have prompted the development of a number of socio-political theories designed to address some of the issues of control, coordination and the development of shared values that we aim for in more suitable approaches to governance.

\subsection{Reflexive modernization}


Reflexive modernization theorists place their argumentation in the context of postindustrial society. The key point of this body of theory is that the processes of globalisation are parallelled by processes of individualisation and that these processes cause or drive the emergence of an increasingly self-critical, reflexive 'risk society' (Beck, 1992; Beck, 1999; Beck and Beck-Gernsheim, 2002). Since the transition from industrial to post-industrial society involves new and often incalculable forms of risk financial, social and environmental - we need new institutions, new practices, new relationships, structures and processes in order to provide adequate governance (Backstrand, 2003).

According to Beck, the individualisation of politics resulting from the retreat of traditional institutions will lead to potentially more inclusive decision-making in a new 'sub-political', extra-parliamentary arena (Beck, 1992). This approach stems from a recognition that traditional systems of authority, be they political, administrative, legal or scientific have facilitated and legitimated modernization processes associated with an institutionalized underestimation of risk. In this context, it is argued that dissatisfaction with the congestion of traditional institutional processes militates in favour of the formation of temporary and multiple stakeholder networks operating as decentralized, self-determining, dynamic, flexible arenas for decision-making will also enable new and more democratic ways of decision making around areas of risk (Beck, 1992). Reflexive modernization theorists argue that these new political structures will not only be more inclusive but will allow the entry of new forms of knowledge resulting from the recognition and admittance of unawareness of the side-effects of industrialisation. Previously closed circles of expert groups, for instance, are confronted with conflicts 
and challenges, leading to the development of what Beck terms 'non-linear knowledge' (Beck, 1998: 96). As Tsoukas (1999: 509) points out, the ongoing 'reflexive monitoring of action' will have major implications for both individuals and organizations.

Arguably, however, as the theory stands, optimisation of the 'sub-political' model relies upon high levels of communication and approximation of consensus between competing interests. Unless the theory is redefined and the process method of decision-making more specifically addressed, the reflexive modernization approach shares the limitations of liberal pluralism (Schlosberg, 1999).

\subsection{Deliberative democracy}

Luskin and Fishkin (2004: 1) define the processes of deliberative decision-making as follows:

Deliberating citizens seek relevant information, reflect on the issues, and exchange views with others. The most valuable kind of deliberation is balanced, taking account of information both convenient and inconvenient to given arguments and alternatives, although much naturally occurring deliberation is of course highly imbalanced.

Based on their research, these writers argue that the process of deliberation increases the political efficacy of individual citizens through enabling better communication of expert information and thus ensuring all interest or community groups can contribute to the critical assessment of the environmental or social issue in question. 
Deliberative decision-making emphasizes the processes of reflection and deliberation, citizens are selected then consider relevant information from a number of different perspectives, are given opportunity for critical conversation on the issues and then reconsider their original opinion (Carson, 2001). Rather than consensus, the aim is to achieve impartiality and full knowledge of critical issues.

The limitations of deliberative decision-making relate to the potential for the deliberative decision-making arena to be influenced by political manipulation and differences in power. However, its techniques are strongly advocated by many public policy and civic science theorists and are noted by Carson in this volume. For instance, deliberative democracy methods which aim to foster public debate through ensuring fuller information can be used to bring together lay, expert and indigenous knowledge and thus establish a more communicative model of science. Such a model is more relevant to decision-making for governance in conditions of uncertainty and risk. As Backstrand (2003) points out, traditional science is not well equipped to deal effectively with the uncertainty characterising many environmental decisions.

\subsection{Radical pluralism}

Radical pluralism has emerged in reaction to the well known problems with classical pluralism, discussed previously. As a critique of classical pluralism, radical pluralism draws from the postmodern concerns for identity, challenging the assumption of 
conventional pluralism that the interest group has an 'essential' identity. According to radical pluralist theory, interest group identity is constructed in relation to others - a process necessarily involving exclusion (Wenman, 2003). As a consequence, diverse viewpoints within interest groups are often suppressed.

Radical pluralism has been taken up by theorists concerned with environmental justice who part company with Beck’s (1992) interpretation of the democratically experienced nature of risk in the 'risk society'. For example, the main concern of the environmental justice movement is that the risks associated with industrial development have been borne by those communities and individuals least able to deal with the consequences of these risks. As well, those groups or individuals within interest groups who are less resourced, either in economic or expert terms, can be marginalized through the process of pluralist interest group construction.

In applying radical pluralism theory to environmental justice issues, Schlosberg (1999) argues that contemporary environmental movements are characteristically pluralistic. They encompass many different understandings of, and experiences with risk but these differences are not recognised by conventional pluralism. According to Schlosberg (1999: 184), if process and content are taken together by applying deliberative principles, both inclusive decision-making and equitable distribution of risk can be achieved. In this case, the deliberative process will allow 'for an institution of discursive practices among a plurality of positions, knowledges and understandings' (1999: 90). Radical pluralism thus brings together Habermas' concepts of ideal forms of 
communication and notions of deliberative democracy with more post-modernist understandings of diversity and identity (Habermas, 1984).

Schlosberg argues that non-hierarchical networks within and between the less-resourced elements of society, such as the environmental justice movement, are a way of organizing against the exploitative 'divide and conquer' strategies often used by corporations and government organizations. The network does not imply unity and admits differences. As Schlosberg says (1999: 118):

It is crucial to note that networks do not necessarily form around one single unifying commonality. Instead, networks form and hold themselves together around numerous issues where there are similarities or solidarities across groups. The resulting mosaic itself - the movement - becomes the major commonality. Within a network there remains both multiplicity and commonality.

\subsection{Ecological democracy}

Suggestions by writers attempting to develop a vision of an ecological democracy are relevant to our defined understanding of governance as the means of enabling a sustaining and coordinating form of action and decision-making between a wide variety of actors. Such writers focus on how to articulate the public interest through the development of a more aware civil society and on governance problems arising from intergenerational and intragenerational issues. 
For instance, Eckersley (2004) argues that, given the short term perspective of policymakers in current democratic systems of liberal pluralism, environmental considerations are inevitably downgraded in the current competition for power. If a democracy is to incorporate ecological concerns it must specifically ensure that collaborative deliberation and problem solving, not competition, underpin governance structures and processes (Eckersley, 2004). Legislation would be specifically designed for the democratic management of risk by enabling the enforcement of the precautionary principle and minimising externalisation of risks through measures such as polluter-pays. Eckersley (2004) envisions that a more active and empowered public is the crucial aspect of a green state. In such a state, extended citizenship rights would enable more inclusive decision-making across a range of stakeholders. She describes a deliberative ideal that is more conducive to reflexive modernization and environmental justice than liberal pluralist bargaining.

Dryzek’s (2000) interpretation of ecological democracy is also built on the concept that more genuine, inclusive forms of communication would ensure more ecologically rational decision-making. He focuses on an achievable, rather than on an idealised, system of ecological democracy. According to Dryzek, the most appropriate political strategy would be to develop a broad public awareness that better governance of the natural environment would benefit all society. 
From even such a brief summary we can see themes emerging in socio-political theory that address governance issues of inclusion and equity not recognised in more traditional pluralist forms of decision-making. The theories draw on key themes of decentralised forms of decision-making, less rigid organizational boundaries to allow for flexibility in decision-making, open and unbiased debate between individual citizens and organizations based on access to information and the building of an aware and educated civil society is necessary in order to build trust between multiple stakeholders that include community, government and corporates and enable creative solutions to intractable social and environmental problems.

In an earlier section we pointed out the limitations of traditional management theory in providing a framework for governance of environmental and social issues that ensures the development of shared stakeholder values. In Table 1 we summarise more recent themes now emerging in the interest areas of critical management studies, narrative theory (Currie, 1998), social issues in management and green business. Table 1 indicates the areas of correspondence between this more radical management theory and emergent themes in socio-political theory that we have identified as having the capacity to incorporate issues of environmental and social impact and risk. The table also points to key issues of importance for governance that are highlighted by these areas of correspondence. For example, narrative theory is an emergent body of management theory which can be applied to understand how stories and narratives can foster the development of shared levels of ecocentric consciousness within and between organizations, leading to a prescription for forms of governance that encourage high levels of communication. 
INSERT TABLE 1 HERE

\subsection{Emergent concepts of governance}

In essence we are arguing that governance of industrial legacies such as toxic waste cannot be relegated to governance theory and practice derived from the theory of either traditional democratic or traditional management and corporate governance theory. Such governance requires the injection of new ways of thinking about environmental values, as well as inclusion and equity through being informed by principles of reflexive modernity, deliberative democracy and networks. Prompted by the numbers of complex and difficult decisions to be made involving many stakeholders beyond business and government, governance as it is now postulated in the public policy, regional development and urban politics literature does address some of these issues. Contemporary writing on governance of social and environmental decision-making that involves multiple stakeholders does not assume that 'governance without government' (Peters and Pierre, 1998) is an end in itself. Rather it assumes that existing practices and use of resources must change if the human species is to survive (Bressers and Kuks, 2003:69, Dovers, 2005:3) and must do so in circumstances where continuing uncertainty is inevitable, and continuing learning and innovation is essential (Rosenbaum and Bressers, 2000:668). Such approaches accept, or even embrace the inevitability of change in the nature of risks or human perceptions of risks and assume that institutions too must have adaptive or reflexive characteristics to cope with changes in the nature and range of stakeholders that need to be engaged in decision-making. This 
involves actively embedding learning in the policy system so that the questions of who to learn from and where to learn become vital components of institutional decisionmaking (Dovers and Connor, 2006:56).

The engagement of multiple stakeholders is justified in this approach not as a 'feint' towards deliberative democracy, but rather as a recognition that environmental crises are interconnected with crises in human relations and decision-making (Boer, 1984). Public participation assists decision-makers in identifying public interest concerns, promotes environmental justice and can enhance accountability and acceptability of environmental decisions, and generally improving our capacity to care for the environment. It has a highly significant role to play in implementation of principles related to application of the precautionary principle in decision making and in comprehending issues associated with inter and intra generational equity (Richardson and Razzaque, 2006:165-6).

Leading writers in the area of governance now argue that good governance in a multiple stakeholder context must encourage recognition by stakeholders of their interdependencies and power differences and the development of a shared will to move beyond the immediate self-interest of the affected parties (Bertels and Vredenburg, 2004; Clarke, 2004). This is an issue addressed by regime theorists in the field of urban politics who argue that building stable coalitions with shared objectives between various levels of government and business is crucial to addressing complex issues such as apparently intractable disputes. These theorists recognise the messy nature of preference 
formation which may be influenced by a whole range of experience, different knowledge bases, social and economic relationships. The stable coalition remains so because it can attract participants through the 'power of social construction' - that is, by the coalition or regime being able to construct a structure which can address the collective problem at hand (Stoker, 1995: 65; Stoker, 1998).

In our view, however, stability and shared objectives that are accompanied by the development of shared values goes beyond mere partnership formation or stable regime formation. For instance, the increasingly prominent discourse of governance by partnership between public, NGO and private sector organizations (eg OECD, 2003) does not address the issues of stakeholder learning, involvement, information and engagement, even if NGO or community based groups are involved. As Head points out, such forms of governance may not ensure that the stakeholders are genuinely working towards shared objectives with a shared sense of values (Head, 2005). Socalled 'organic' models of governance are more networked and avoid the top down and inflexible approaches incompatible with a reflexive or deliberative system (Potapchuck, Crocker and Schahter, 1999). The 'organic' model focuses on the governance of networks, diverse policy actors or coalitions which can include organizations of differing types as well as individual members of the community (European Commission, 2000; Jones, Hesterly and Borgatti, 1997). The goal is to develop problem-solving as an ongoing process of deliberation and mutual learning between diverse publics or stakeholders (Carlsson and Berkes, 2005). This is different from a consensus-seeking approach - the process is based on a clear recognition of the different values and interests of the various parties involved and a deep exploration of these 
differences rather than their smoothing over. These procedures are best developed if deliberative democracy principles are employed to ensure that the diversity of the interest groups is recognised and built on in order to extend the reflexive capacity of the risk community and deliver creative outcomes (Dedeurwaerdere, 2002).

The concepts of network or horizontal governance do appear to address some of the key themes highlighted by socio-political theorists, such as in Beck's original concepts of the 'sub-political' arena associated with reflexive modernization and the other key issues for governance such as diversity, flexibility, high levels of communication and reflexivity that are highlighted in Table 1. According to Head (2005: 138) this horizontal form of governance has fundamental advantages for the conditions we focus on in this volume:

The fundamental themes here are concerned with closer and more complex relations between the state and civil society; embedding NGOs in the design, delivery and evaluation of programs; some devolution of government power; and a sharing of responsibility between stakeholder groups and bodies for achieving outcomes in policy and program areas that have been regarded as complex or intractable.

\subsection{Towards a horizontal process-based approach to governance}

Such a governance system as we have idealized must be based in processes such as those of 'meet-understand-manage', where multiple voices and different kinds of knowledge are heard rather than rules and regulations (Parr, Sier, Battarbee, Mackay 
and Burgess, 2003: 5). But the case of HCB disposal discussed in this volume illustrates than establishing such a system has four substantial problems to overcome: The first problem is that resolving an environmental issue like the disposal of Orica's HCB wastes demands considerable expert knowledge which lay members of a local community are unlikely to possess. As Schneider (1997: 143) has written:

The social problem of science policy making then becomes how to make non expert communities knowledgeable about what a broad cross section of relevant experts thinks might happen and what the probabilities of those occurrences are. Most important, of course, is some guidance on what the impacts of such occurrences could imply for environment and society. That consensus-assessment process is inherently a social activity - therefore not one for which the scientific method directly applies - and this makes many scientists edgy.

In the Orica case, for example, initially the Botany community did not have the technical knowledge needed to understand the problem they were faced with. However over time they did acquire quite deep technical understanding of HCBs and of alternative waste disposal methods. This required, however, active networking and was time consuming for a small group of committed volunteers.

The second problem is how to manage what are often substantial power and resource differences between the various stakeholders. In the Orica case, for example, the company had more ready access than community groups to government bureaucracies, politicians and in-house expertise and external advisers. 
The third problem has to do with the level of complexity of particular environmental issues. Although our insights from political theory have pointed us in the direction of a decentralised model, we note that such forms of inter-organizational governance may also need to be operational at other levels than the immediate neighbourhood. In the case of the Botany dispute over HCB disposal, for instance, certain aspects of the decision-making could only take place at regional and national levels, illustrating what Bressers and Kuks (2003) have labeled the essentially multilevel nature of governance concerning environmental issues

The fourth problem is to ensure that the values of the organizations and individuals involved support the search for realistic longer term solutions. Most organizations need cultural development to foster the creative capacity needed to develop policy and map out possible solutions. In particular large corporations need a culture more accepting of disorder, more willing to recognise that contestation and challenge can lead to an enhanced capacity for reflexive management.

\subsection{Implementing the process of horizontal governance}

The process of implementing this approach to governance requires practical strategies for consultation between organizations, the community and individuals. In this section we outline the issues with which these decision-making processes must deal and we 
suggest some relevant tools and processes which can be adapted for use in creating an effective decision-making process. Table 2 lists these issues.

Table 2: Issues to be addressed in the process of horizontal governance Insert Table 2 here

The issues listed above are set out in roughly chronological order but we emphasise that these issues have to be dealt with iteratively and cannot be resolved in a simple linear sequence. We briefly discuss each of the issue sets in Table 2; in doing so, we also draw upon well documented and widely used problem analysis and collective decisionmaking processes from the action oriented fields of deliberative democracy, organization development and community development to create a practical process for constructing an evolving organic governance system.

The first issue, identifying the 'sub political' arena, involves some authority, group or organization identifying the nature of the risk that needs to be addressed and sketching out the relevant sub-political arena (Beck, 1992; 1999). We recognise that the determination of who are the stakeholders and who should be included in the subpolitical governance process is not as simple as it may appear. A useful introduction in determining who relevant stakeholders are can be found in Carroll (2000). As Cousins (2005: 37) states: “The challenge for sustainability-focused governance is to engage with, balance the interests of all stakeholders and seek to avoid, in Dryzek's terms, the displacement of problems to other people, places and times.” 
In considering the processes and tools could be employed at this stage of decisionmaking that would optimise the chances of success we look to an extensively used process by organization development/organizational change consultants is the Search Conference and variants known as 'Future Search', 'Participatory Strategic Planning' and 'The Strategic Forum'. These participatory diagnostic approaches are well documented by Holman and Devane (1999). Diagnostic tools specifically designed to provide information on the risk issue and that can be readily combined with the search conference process are provided by Luginaah, Eyles and Elliot (2004). The tools include focus groups and targeted interviews. These tools aim to determine which groups or individuals may be exposed to risk, the nature of the exposure and the degree of the exposure. Other relevant tools can be drawn from work in the Appreciative Inquiry tradition but need to be adapted for use in risk management deliberations (see, for example, Cooperrider, 1996).

The second issue involves identifying the power and resource differences between stakeholders. Other contributors to this volume discus how, in the Orica case, significant differences in power, knowledge and resources between the various stakeholders involved remained unaddressed over the period of decision-making described in this volume. Luuginaah et al (2004) provide scanning tools which allow for the assessment of the socio-political context, identification of relevant stakeholders and the classification of these groups to map out the influence structure. In our view these tools need some further work to differentiate more specifically between relative access to power, resources such as finance and awareness/knowledge, that is, the bases of relative power differentials between the participating parties). 
The third issue involves actually creating the 'community of interest and dispute' network, that is, bringing the key stakeholders together into a network that has the potential to deliver deliberative dialogue. The aim is to ensure that members of the network are engaged in meaningful exploratory dialogue and that they become committed to reaching a solution beyond their immediate individual self interests. It is vital that both commonalities and differences in views are explored, that areas where there is insufficient shared knowledge are identified and that a rush to superficial consensus is resisted. The challenge is to create a 'transactional space'. Transactional spaces refer to "places that have legitimacy - where all the cards are on the table...a transactional space requires all perspectives to be put on the table as an absolute prerequisite” (Attributed to Gristock by Buselich, 2005: 306).

Luginaah et al (2004) provide 'impact tools' which allow assessment of how risks impact on different stakeholders and how these impacts can be mitigated. As the risk issue frequently shifts over time, these tools help stakeholders to respond to new circumstances. Another useful tool that can help the collective development of priority issues and move the parties toward accepted solutions is the Delphi Method which is basically a method of gaining the response of a panel of geographically dispersed experts to a complex problem (see Loo, 2002). Although it has encountered some criticism in its relatively long history as methodologically unscientific (eg Sackman, 1974), the Delphi Method is still widely used as a communication tool to gain expert opinion. These qualitative tools designed to help map stakeholder response can lead to stakeholders accepting diversity and respecting differences in perception. This is the 
beginning of the trust building process that is the key to the development of shared values - a point well recognized in the extensive literature on social capital (eg Adler and Kwon, 2002).

The fourth issue involves negotiating the deliberative strategies that are at the heart of the risk resolution process. Hard decisions need to be made about issues such as which parties will be represented going forward in the evolving deliberative process and at what stages they will participate. It also needs to be decided whether they will participate directly or on a representative basis. Other vital areas of decision are listed in Table 2 above. Suitable process methodologies for this stage are provided in Holman and Devane (1999). Where the community is involved 'consensus conferencing' provides a method of assisting citizens participate in an informed way in policy debates about complex and challenging issues. In this process, dialogue takes place between a panel of citizens and a panel of leading experts. In the instance of the HCB dispute, the 'experts' would be drawn from relevant areas of the natural and social sciences, and would reflect administrative and academic knowledges and capacities. The process works like a citizens' jury where a representative group of people deliberate on an issue with the assistance of a facilitator and experts to review their areas of agreement and differences and seek common ground for action (Carson, 2001). The issue of who should fund this process raises a dilemma. Should the polluter pay or will this inevitably be seen as corporate capture (see Healy, this volume)? Our suggestion is that the process should be funded by an independent fund, an environmental trust contributed to by polluters but administered at a distance from them. The process itself is 'managed' by the independent facilitator. 
The final and fifth issue involves implementing the decisions which have emerged from the decision-making process. This involves developing practical plans to eliminate and minimize risks and to share equitably the remaining potential risks; to assign responsibilities for actioning the plan, to allocate costs and to design ongoing monitoring systems. Most project managers working in large enterprises, including NGOs, government organizations and corporations are familiar with a range of processes and tools appropriate to this stage. It is our view that

\subsection{Conclusion}

We end by emphasizing some central ideas we have advanced for a process of governance that enable control, coordination and the development of shared values across a multiple stakeholder arena of decision-making such as the disposal of the toxic waste discussed in this volume. The goal is inclusion based on recognition of diversity using and developing decentralised networks, including community-based networks. Resulting shifts in practice entail a replacement of short-termism by long-termism and a balancing of organizational competition with interdependence and mutuality. Yet we have argued that this ideal cannot be achieved without innovative practices fostered by a governance system which enables debate, challenges the established order and uses embeddedness and interconnectedness to foster the exchange of ideas and values. We also reviewed several practical approaches to problem definition, decision-making and action planning that represent tested strategies to be integrated into an emergent set of participative processes for decision-making in the sub political arena. We hope that, as 
new horizontal governance systems for dealing with environmental impact and risk of industry and business develop, the production of intractable wastes will cease and there will be more equitable distribution of any remaining risks arising from the activities of companies.

\section{References}

Adler, P.S., Kwon, S.-W., 2002. Social Capital: Prospects for a new concept. Academy of Management Review, 27 (1), 17-40.

Backstrand, K., 2003. Civic science for sustainability: Reframing the role of experts, policy-makers and citizens in environmental governance. Global Environmental Politics, 3(4), 24-41.

Banerjee, S. B., 2005. Who sustains whose development? Sustainable development and the reinvention of nature. Organization Studies, 24 (1): 143-180.

Beck, U., 1992. (trans. Mark Ritter) The risk society. $1^{\text {st }}$ ed. Sage Publications, London. Beck, U., 1998. Democracy without enemies, Polity Press, Cambridge.

Beck, U., 1999. World risk society. $1^{\text {st }}$ ed. Polity Press, Cambridge.

Beck, U., Beck-Gernsheim, E., 2002. Instituitionalized Individualism and Its Social and Political Consequences (Theory, Culture and Society Series). 1st ed Sage Publications, London.

Benn, S., Jones, R. (this volume) The role of symbolic capital in stakeholder disputes: Decision-making concerning intractable wastes . 
Bergkamp, L., 2002. Corporate governance and social responsibility: A new sustainability paradigm. European Environmental Law Review, May, 136-152. Bertels, S., Vredenburg, H., 2004. Broadening the notion of governance from the organization to the domain: A study of municipal water systems in Canada. Special issue, Towards Better Governance and Accountability: Exploring the Relationships between the Public, Private and the Community, in: Demirag. I., (ed) Journal of Corporate Citizenship, 15, 33-47.

Blattberg. C. 2000. From Pluralist to Patriotic Politics. Oxford University Press, Oxford. Boer, B., 1984. Social Ecology and Environmental Law. Environmental and Planning Law Journal, 1, 233-257.

Bressers, H. T. A., Kuks, S. M. M., 2003. What Does "Governance" Mean? From Conception to Elaboration, in: H.T.A.Bressers, W.A.Rosenbaum (eds) Achieving Sustainable Development. The Challenge of Governance Across Social Scales. Praeger, London, pp. 65-88.

Buselich, K., 2005. Transactional Space: A Transformative Process for Sustainability Deliberation Piloted with the Western Australian Collaboration, in: W Filho (ed), Handbook of Sustainability Research. Peter Lang, Frankfurt, pp.297.

Carlsson, L., Berkes, F., 2005. Co-management: concepts and methodological implications. Journal of Environmental Management, 75, 65-76.

Carroll, A., 2000. Conceptual and Consulting Aspects of Stakeholder Theory, Thinking and Management, in: R. T. Golembiewski, Handbook of Organizational Consulting. $2^{\text {nd }}$ ed. Marcel Dekker, New York, pp. 169.

Carson, L., this volume. Deliberative democracy and hexachlorobenzene stockpiles 
Carson, L., 2001. Innovative consultation processes and the changing role of activism. Third Sector Review, 7(1), 7.

Clarke, T., 2004. Introduction: theories of governance - reconceptualising corporate governance theory after the Enron experience, in: Clarke T (ed), Theories of Corporate Governance. $1^{\text {st }}$ ed .Routledge, London, pp. 1 - 32.

Cooperrider, D.L., 1996. Appreciative Inquiry, Cleveland. Weatherhead School of Management, Case Western Reserve University.

Crane, A., 2000. Corporate greening as amoralization. Organization Studies, 21(4), 673697.

CSR Gov UK. Available at: http://www.csr.gov.uk/whatiscsr.shtml (accessed 13 July 2006.)

Cousins, R., 2005. A Theoretical Framework for Measuring the Sustainability Capacity of Modes of Governance, in: W L Filho, Handbook of Sustainability Research. Peter Lang, Frankfurt, pp. 31.

Currie, M., 1998. Postmodern Narrative Theory. St. Martin's P, New York.

Dawson, S., 2004. Balancing self-interest and altruism: corporate governance alone is not enough. Corporate Governance, 12, 130-133.

Dawkins, S., 2004. Corporate responsibility: the communication challenge. Journal of Communication Management, 9, 108-119.

Dedeurwaerdere, T., 2002. Ethics and Learning: From State Regulation towards Reflexive Self-Regulation of the Information Society. Paper presented at the World Computer Congress, Montreal Available from http://dlc.dlib.indiana.edu/archive/00000634/00/Reflexive_Selfreg_of_the_Internet.PDF (accessed 15 July 2006) 
Dovers, S., 2005. Environment and Sustainability Policy: Creation, Implementation, Evaluation. Federation Press, Leichhardt.

Dovers, S. and Connor, R., 2006. Institutions and Policy Change for Sustainability, in Richardson, B. J., Wood, S., (eds) Environmental Law for Sustainability. Hart Publishing, Oxford and Portland, pp.21-60.

Dryzek, J., 2000. Deliberative Democracy and Beyond, 1st ed. Oxford University Press, Oxford.

Eckersley, R., 1992. Environmentalism and Political Theory. $1^{\text {st }}$ ed. State University of New York Press, Albany.

Eckersley, R., 2004. The Green State - Rethinking Democracy and Sovereignty. 1st ed. MIT Press, Cambridge, MA.

Ehrenfeld, J., 2000. Industrial Ecology. American Behavioral Scientist. 44 (ed 2), 229245.

Elkington, J., 1998. Cannibals with Forks: The Triple Bottom Line of 21st Century Business. $1^{\text {st }}$ ed. Capstone Press, Oxford.

European Commission, 2000. “The Future of Parliamentary Democracy: Transition and Challenge in European Governance”Green Paper prepared for the Conference of the European Union Speakers of Parliament, September 2000. Online. Available at: http://ec.europa.eu/governance/docs/doc3_en.pdf (accessed 12 December 2006.)

Farrell, C., Morris, J., 2003. The ‘Neo-Bureaucratic’ State. Organization, 10(1), 129156.

Freeman, R., 1984. Strategic Planning: A Stakeholder Approach. Pitman Publishing, London. 
Gladwin, T., Kennelly, J., Krause, T., 1995. Shifting paradigms for sustainable development: implications for management theory and research. Academy of Management Review, 20(4), 874-908.

Goodin, R., 1992.Green Political Theory. $1^{\text {st }}$ ed. Polity Press, Cambridge.

Grace, D., Cohen, S., 1998. Business Ethics. $2^{\text {nd }}$ ed. Oxford University Press, Melbourne.

Grayson, D., Hodges, A., 2004. Corporate Social Opportunity: Seven Steps to Make Corporate Social Responsibility Work for Business. 1st ed. Greenleaf Publications, London.

Habermas. J., 1984. Theory of Communicative Action Volume 2. 1st ed. Beacon Press, Boston.

Hawken, P., Lovins, A., Lovins, H.L, 1999. Natural capitalism: creating the next industrial revolution. 1st ed. Little, Brown and Company, New York.

Head, B., 2005. Participation or Co-Governance? Challenges for Regional Natural Resource Management, in: R. Eversole, J. Martin (eds) Participation and Governance in Regional Development. Ashgate Publishing , Hampshire, pp. 137-154.

Healy, S. Toward an epistemology of public participation. This volume. Holman, P., Devane, T., 1999. The Change Handbook: Group Methods for Changing the Future. Berrett-Koehler, San Francisco. James, P., The supervision of environmental risks: the community of Botany/Randwick. This volume.

Jensen-Lee, C. When unequals are treated equally: The 2002 Commission of Inquiry into Orica's Geomelt Proposal. This volume. 
Jones, C., Hesterly, W., Borgatti, S., 1997. A General Theory of Network Governance: Exchange Conditions and Social Mechanisms. Academy of Management Review, 22, 911-945.

Kochan, T., 2003. Restoring trust in American corporations: Addressing the root cause. Journal of Management and Governance, 7, 223-231.

Kooiman, J., 1993. Modern Governance. Sage Publications, London and Thousand Oaks.

Livesey, S., 2003. Organizing and leading the grassroots. Organization and Environment, 16, 470-473.

Lloyd-Smith, M. Information, power and environmental justice in Botany: the role of community information systems. This volume.

Loo, R., 2002. The Delphi Method: A powerful tool for strategic management. Policing: an International Journal for Police Strategies and Management, 25, 762-769.

Luginaah, I., Eyles J., Elliott, S., 2004. Informing the Development of Decision Support Tools for Risk Management: The Case of Electrical and Magnetic Fields. Journal of Environmental Planning and Management, 47( 4), 601-621.

Luskin, R., Fishkin,J., 2004. Deliberation and Better Citizens. Centre for Deliberative Democracy, Stanford University. Online. Available at:

http://cdd.stanford.edu/research/index.html. Accessed 1 October 2004.

Miller, D., 1993. Deliberative democracy and social choice, in D. Held (ed), Prospects for Democracy: North, South, East, West. 1st ed. Polity Press, Cambridge, pp. 74-92. Newton, T., Harte, G., 1997. Green business: Technicist kitsch?. Journal of Management Studies, 34, 75-98.

OECD, 2003 Open Government: Fostering Dialogue with Civil Society. OECD Paris. 
Orts, E., 2002. The ethical and environmental limits of stakeholder theory. Business Ethics Quarterly, 12 (2), 215-233.

Parr, T., Sier, A., Battarbee, R., Mackay, A., Burgess, J., 2003. Detecting

Environmental Change: science and society - perspectives on long-term research and monitoring in $20^{\text {th }}$ century. The Science of the Total Environment, 310, 1-8.

Peters, B. G., Pierre, J., 1998. Governance Without Government? Rethinking Public Administration. Journal of Public Administration and Theory, 18, 223-243.

Pierre, J., 2000. Introduction : Understanding Governance, in: J. Pierre (ed) Debating Governance, Oxford University Press, Oxford, pp. 1-6.

Porter, M., 1980.Competitive Strategy. $1^{\text {st }}$ ed. The Free Press, New York.

Potapchuk, W., Crocker, J., Schechter, W., 1999. The Transformative Power of Governance. National Civic Review, 88 (3), 217-248.

Richardson, B. J., Razzaque, J., 2006. Public Participation in Environmental Decisionmaking, in: Richardson, B. J., Wood, S., (eds) Environmental Law for Sustainability. Hart Publishing, Oxford and Portland, pp. 165-194.

Rosenbaum, W. A., Bressers, H. T. A., 2000. Uncertainty as Environmental Education. Policy Studies Journal, 28, 668-671.

Schlosberg, D., 1999. Environmental justice and the new pluralism: The challenge of Difference for Environmentalism. $1^{\text {st }}$ ed. Oxford University Press, Oxford.

Sackman, H., 1974. Delphi assessment : expert opinion, forecasting, and group process. Rand, California.

Schneider, S., 1997. Laboratory Earth: The planetary gamble we can’t afford to lose. Basic Books, New York. 
Shrivastava, P., 1995. Ecocentric management in a risk society. The Academy of Management Review, 20(1), 118-138.

Starik, M., Rands. G., 1995. Weaving an integrated web: Multilevel and multisystem perspectives in ecological sustainability organizations. Academy of Management Review, 20 (4), 908-935.

Starkey, K., Crane, A., 2003. Epic. Academy of Management Review, 28(2), 220-238. Sternberg, E., 2000. How the strategic framework for UK company law reform undermines corporate governance. Hume Papers on Public Policy, 8, 54-73. Stewart, J., Jones, G., 2003. Renegotiating the Environment. $1^{\text {st }}$ ed. The Federation Press, Sydney.

Stoker, G., 1995. Regime Theory and Urban Politics, in: D. Judge, G. Stoker, H. Wolman (eds), Theories of Urban Politics. Sage Publications, London, pp. 54. Stoker, G., 1998. Public-Private Partnerships and Urban Governance, in: J. Pierre (ed) Partnerships in Urban Governance. MacMillan Press, Hampshire, pp. 33-51. Sundaramurthy, C., Lewis, M., 2003. Control and collaboration: paradoxes of governance. Academy of Management Review, 28(3), 397-415.

Tsoukas, H., 1999. David and Goliath in the risk society: Making sense of the conflict between Shell and Greenpeace in the North Sea. Organization, 6, 499-528.

Waddock, S., Bodwell, C., Graves, S., 2002. Responsibility: The new business imperative. Academy of Management Executive, 16(2), 132-149.

Warhurst, A., 2001. Corporate citizenship as corporate social investment. Journal of Corporate Citizenship, 1, 57-73.

Wenman, M., 2003. What is Politics? The Approach of Radical Pluralism. Politics, 23(1), 57-65. 
Zadek, S., 2001. The Civil Corporation: The new economy of Corporate Citizenship. $1^{\text {st }}$ ed. Earthscan Publications, London.

TABLE 1 Areas of correspondence between emergent socio-political and management theory

\begin{tabular}{|c|c|c|c|c|}
\hline $\begin{array}{l}\text { Emergent } \\
\text { political } \\
\text { theory }\end{array}$ & $\begin{array}{l}\text { Key } \\
\text { contribution }\end{array}$ & $\begin{array}{l}\text { Critical } \\
\text { management } \\
\text { theory }\end{array}$ & $\begin{array}{l}\text { Areas of } \\
\text { correspondence }\end{array}$ & $\begin{array}{l}\text { Key issue for } \\
\text { governance }\end{array}$ \\
\hline $\begin{array}{l}\text { Reflexive } \\
\text { modernization }\end{array}$ & $\begin{array}{l}\text { A } \\
\text { decentralised } \\
\text { 'sub-political' } \\
\text { arena enables } \\
\text { reflexive and } \\
\text { inclusive } \\
\text { decision- } \\
\text { making }\end{array}$ & $\begin{array}{l}\text { Stakeholder } \\
\text { interaction }\end{array}$ & $\begin{array}{l}\text { Community-based } \\
\text { networks involving } \\
\text { multiple stakeholder } \\
\text { link different types of } \\
\text { knowledge and } \\
\text { facilitate knowledge } \\
\text { development and } \\
\text { diffusion. }\end{array}$ & $\begin{array}{l}\text { Decentralised } \\
\text { governance }\end{array}$ \\
\hline $\begin{array}{l}\text { Deliberative } \\
\text { democracy }\end{array}$ & $\begin{array}{l}\text { Open and } \\
\text { critical debate } \\
\text { can increase } \\
\text { awareness and } \\
\text { the political } \\
\text { efficacy of all } \\
\text { participants }\end{array}$ & $\begin{array}{l}\text { Narrative } \\
\text { theory }\end{array}$ & $\begin{array}{l}\text { Defamiliarising } \\
\text { narratives and } \\
\text { storytelling can develop } \\
\text { a shared 'ecocentric' } \\
\text { understanding across } \\
\text { organizations }\end{array}$ & $\begin{array}{l}\text { Governance } \\
\text { based on high } \\
\text { communication } \\
\text { frequency }\end{array}$ \\
\hline
\end{tabular}




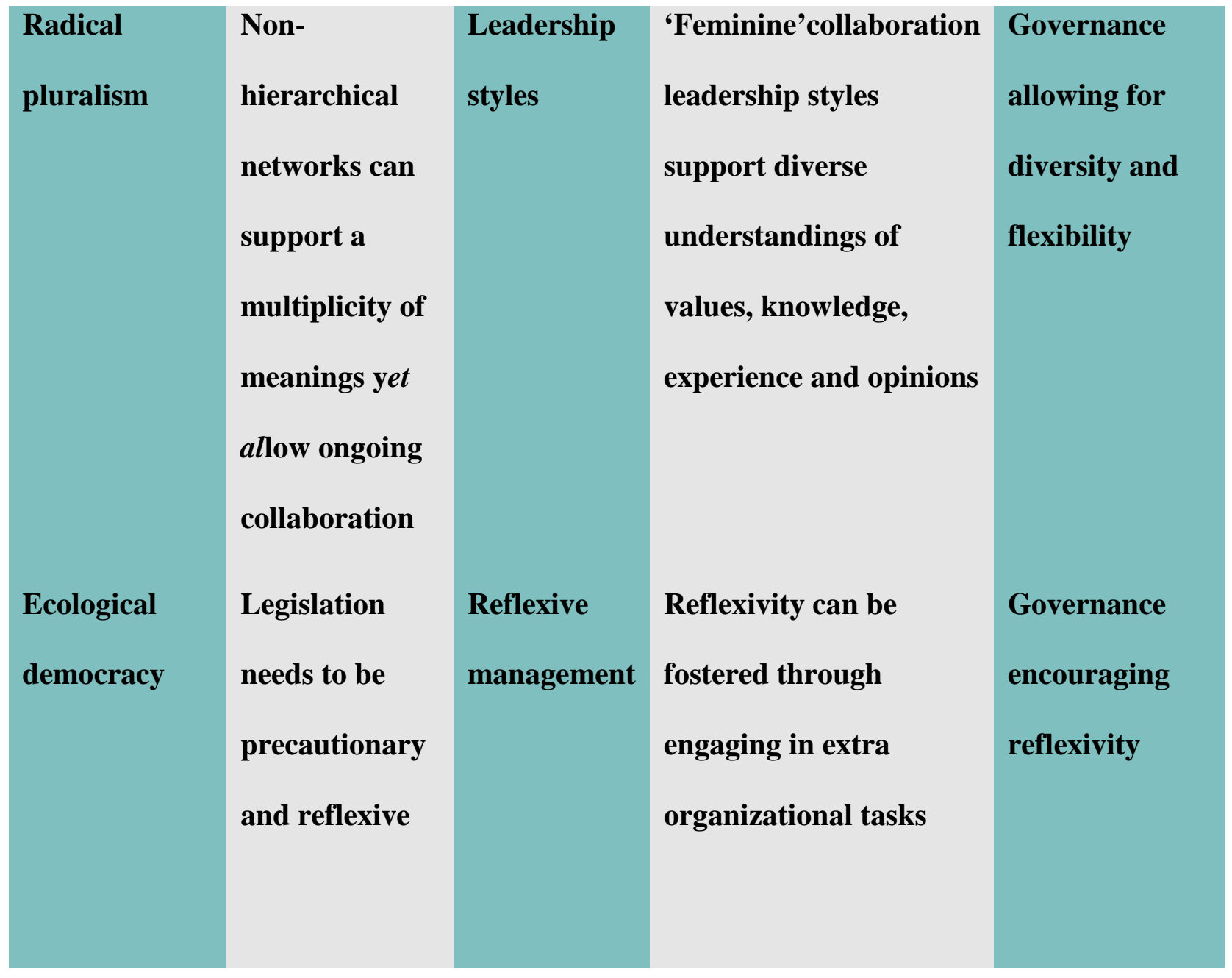


Table 2 : Issues to be addressed in a new model of environmental governance

Factor 1. Identifying the 'sub political' arena:

- nature of the risk

- scope of the risk; extent of risk, ie who is at greatest/least risk

- relevant stakeholders, ie those potentially affected by the risk

- the boundaries of the sub political arena

Factor 2. Identifying key interests of and differences between stakeholders

- $\quad$ key interests

- $\quad$ power differences

- $\quad$ resource differences

- awareness and knowledge differences

- identifying relative advantage/disadvantage among stakeholders and their support needs

Factor 3. Creating the ‘community of interest and dispute’ network:

- bringing stakeholders or their representatives together

- undertaking preliminary discussions

- refining the identity of the sub political arena (see Factor 1 above)

- identifying sources of required expertise

- joint mapping of common and differing interests of stakeholder groups including diversity within groups (refining Factor 2 above) 
- identifying core values of stakeholder groups

Factor 4. Negotiating the deliberative strategies:

- deciding on direct or indirect representation of parties

- appointing a coordinator or coordinators and process facilitator(s)

- designing deliberative procedures including communication options

- developing a timeline for the process and anticipated stages

- gaining agreement to decision-making methods including how the final decision will be reached

- providing for arbitration in case of failure to reach agreement - either a 'citizen’s jury’ or an arbitrator; agreeing how these will be chosen, appointed, constituted.

- designing support to overcome relative disadvantages identified in 2 above (achieving equity in resource availability; compensating for relative power, resource and knowledge differentials.

Factor 5. Implementing the decisions:

- developing practical plans to eliminate, minimize and manage risk

- assigning responsibilities for actioning the plan

- assigning costs of actioning the plan

- designing and implementing monitoring systems to ensure that plans are achieved. 